\title{
Enforcement of Food Legislation and Its Impact on Food Safety: A Case Study on Food Law Enactment in Mauritius
}

\author{
Said Ajlouni, Yousof Gaungoo \\ The University of Melbourne, Melbourne, Australia \\ Email: said@unimelb.edu.au,ygaungoo@student.unimelb.edu.au
}

How to cite this paper: Ajlouni, S. and Gaungoo, Y. (2018) Enforcement of Food Legislation and Its Impact on Food Safety: A Case Study on Food Law Enactment in Mauritius. Advances in Microbiology, 8, 101-124.

https://doi.org/10.4236/aim.2018.82008

Received: December 14, 2017

Accepted: February 25, 2018

Published: February 28, 2018

Copyright ( 2018 by authors and Scientific Research Publishing Inc. This work is licensed under the Creative Commons Attribution International License (CC BY 4.0).

http://creativecommons.org/licenses/by/4.0/

\section{cc) (i) Open Access}

\begin{abstract}
Foodborne diseases affect human health and cause significant economic loss. Among the proposed mitigating strategies to prevent, or at least, to reduce foodborne diseases were the enactment and proper enforcement of food legislation. In Mauritius (MU), many outbreaks have been reported since the enactment and enforcement of the Food Act 1998 (MU) and Food Regulations 1999 (MU). Therefore, it was high time to re-evaluate the impact of the food law on the pattern of foodborne diseases. The aim of this study was to evaluate how the introduction of the Mauritian food legislation had influenced the pattern of foodborne diseases and its suitability in recent years. Data were collected from the website of the Ministry of Health and Quality of Life of Mauritius from 1990 to 2015 and analysed using nonparametric statistical methods, where required. Results showed that more foodborne disease cases occurred during enforcement of the food legislation than before. The study also found that the food law was consistently enforced over the years, except during epidemics of chikungunya fever and dengue fever. Furthermore, several strengths and weaknesses were identified in the current legislation related to the risk of foodborne diseases. Comparing the Mauritian with the Australian food laws revealed some similarities and differences between the two legislations. This review showed that overall foodborne diseases in Mauritius increased and were not affected by the food law enforcement. Therefore, a revision of the law and its enforcement is necessary to make them more efficient in preventing foodborne diseases.
\end{abstract}

\section{Keywords}

Mauritius, Foodborne Disease, Food Legislation, Food Safety, Australian Food Law 


\section{Introduction}

Foodborne diseases can be defined as those conditions, which are usually communicated through consumption of food. And they include a wide range of illnesses caused by enteric pathogens, parasites, chemical contaminants and toxins, adulterating food at different points in the food supply [1]. Foodborne diseases of microbiological origin belong to two types, foodborne infection, resulting from consuming food containing viable pathogenic microorganisms or foodborne toxin [2]. It has been reported that foodborne diseases contribute significantly to the morbidity, disability and death rate worldwide [3]. For example, in the United States of America (USA), around 9.4 million cases of foodborne diseases are reported each year due to the consumption of contaminated food [4]. Additionally, every year, approximately 2.2 million people die from diarrhoeal diseases worldwide, among which a large proportion is caused by the ingestion of contaminated food [5] [6]. In fact, published epidemiological data related to foodborne illnesses represent only a fraction of the real number of casualties, as many incidents go unreported [7]. The same authors argued that for surveillance systems to capture cases, the sick persons should report to a health institution to provide the specimen, which must be confirmed by laboratory examination. Therefore, if patients, particularly those with mild symptoms, do not report to health institutions, the cases will not be recorded.

In addition to human suffering, foodborne diseases are usually associated with a high economical cost for the public, the food industry, the health care services, and the government [8]. The yearly estimates for the overall economic cost of foodborne illnesses have been reported in some countries. For example, in the USA it was estimated to be $10-83$ billion USD [9], whereas, in Sweden the figure was 1.1 billion Swedish Krona [10], in Australia 1.25 billion AUD [11], in New Zealand 86 million NZD [12], and in South Korea 954.9 billion South Korean Won [13].

A breakdown of the economic cost related to food borne illnesses showed that the food industry was affected in terms of workdays and productivity loss, closure of food establishments by the authority, loss of reputation, cost of legal actions initiated by authorities, cost of internal investigations, and civil actions by victims, loss of production, and additional cost of disinfection procedures [14]. For example, in the 1990's, "Jack in the Box", a fast food company in the USA, paid damages amounting to more than 50 million USD to victims who suffered foodborne infections following consumption of hamburgers contaminated with Escherichia coli O157:H7 [15]. Another area, which incurred economic cost during foodborne illnesses, was the health care services, in terms of hospitalisations, attending emergency departments, visits to general practitioners, specialist services, diagnostic testing and pharmaceutical expenses [11]. The same authors estimated that the total annual healthcare cost for foodborne gastroenteritis in Australia was approximately 200 million AUD in 2002.

Several strategies have been proposed to curb the incidence of foodborne dis- 
eases and to reduce human suffering, as well as, economic cost. Bryan [16] suggested the importance of food legislation and its enforcement together with education and training.

In Mauritius (MU), the responsibility to ensure the safety of food available on the market rests mainly upon the Ministry of Health and Quality of Life (MOHQL), through enforcement of the Food Act 1998 (MU) and Food Regulations 1999 (MU) [17]. In fact, these food laws have been enacted since 1998, when food safety became a major concern for the government due to the social and economic costs of foodborne diseases. Furthermore, as the tourism industry was an important pillar of the Mauritian economy, it was essential to come up with measures to guarantee the safety of international visitors.

However, after more than fifteen years since the enactment of the food legislation in Mauritius, news in the local press suggested an increase in foodborne disease outbreaks in recent years [17].

This review aimed to: 1) identify whether the implementation of Mauritian food law was able to reduce the incidence of foodborne diseases caused by pathogenic microorganisms; and 2) examine the Mauritian food law and compare its strengths and weaknesses with the Australian food legislation, namely the Food Act in Victoria (1984) and the Australia New Zealand Food Standards Code (2003) [18]. The Victorian food act was used because the study was conducted at The University Melbourne in the State of Victoria.

To the best of authors' knowledge, no such study on Mauritian food law had been done before. Consequently, results from this investigation can be used to recommend changes to the current Mauritian food policy documents and legislation in order to improve food safety and reduce foodborne diseases.

\section{The Island of Mauritius}

Mauritius is an upper-middle income island nation of 1.26 million people, located in the southwest of the Indian Ocean [19]. It is composed of 10 districts, namely, Port Louis, Pamplemousses, Riviere du Rempart, Flacq, Grand Port, Savanne, Plaine Wilhems, Moka, Black River and the island of Rodrigues [20]. All these districts, except Port Louis and Plaine Wilhems are considered as rural regions, while, both Port Louis and Plaine Wilhems as urban regions. According to Statistics Mauritius [19] the ratio of the rural to urban Mauritian population is $3: 2$.

There are two seasons in the country, namely, summer, which extends from November to April, and winter from June to September, with October and May as transitional months. The average temperature in Mauritius ranges from $31.5^{\circ} \mathrm{C}$ to $34.4^{\circ} \mathrm{C}[20]$.

\section{Food Safety and Hazard Analysis Critical Control Points (HACCP)}

Food is one of the essential basic human needs, however, the consumption of contaminated foods can cause diseases and even death [21]. Consequently, ensuring 
food safety, and preventing foodborne disease outbreaks among the public, continue to be of a high priority in both developed and developing countries [22]. For example, in 2009, the US President, Mr. Barack Obama, stated, "there are certain things only a government can do. And one of those things is ensuring the foods we eat are safe and do not cause us harm" [23]. A similar commitment to ensure food safety was undertaken by the Mauritian government in 2012, promising to implement a National Food Safety Action Plan, with focus on enhancing inspection activities and capacity building, and reviewing existing food legislations, and quality control [24].

The food authorities and the scientific community have identified the main contributors to foodborne diseases to include, incorrect cooking procedures, wrong storage temperature, poor hygiene and sanitation among food handlers, cross-contamination and sourcing food from doubtful origin [22]. However, despite all efforts, in terms of information campaigns and education highlighting these factors, foodborne diseases are still having a significant impact on human health [21] [25]. In fact, it is a big challenge to compel operators along the food supply chain, from farm to fork, to implement food safety practices [26]. Therefore, in addition to the fundamentals of food safety management and legislation, it is essential for food business operators to adopt a good food safety culture in terms of attitude and practices [27]. Griffith et al. [28] proposed six culture practices that could enhance food safety performance. These practices are leadership, food safety management and style, dedication to food safety, food safety environment, risk perception and communication. It was reported that failure to implement a good food safety culture caused an E. coli O157:H7 outbreak in South Wales (United Kingdom) in 2005 due to cross-contamination between raw and ready-to-eat food [26].

Foodborne diseases result from the failure or inability to control hazards at one or more unit operations in the food chain from farm to fork [29]. According to the same author, traditional examination of food for screening of hazards does not provide $100 \%$ safety assurance, due to sampling procedures and the nature of microorganisms present in the food. In other words, analysis of a sample of food from a batch of food does not guarantee that the remaining untested portion is safe for human consumption. However, food safety management system, such as, the Hazard Analysis Critical Control Point (HACCP), offers an additional measure to ensure food safety [23] [30]. HACCP was developed in the USA by the National Aeronautics Space Administration (NASA) together with other organisations in the 1960's to produce safe food for space expeditions [15] [31]. According to those authors, it was designed to control potential hazards at critical control points during food processing. Since then, HACCP system has proved to be a very reliable way to ensure food safety and has been adopted by the food industry and regulatory agencies to reduce foodborne diseases [32] [33]. In addition, because of globalisation and international commitments, HACCP has become mandatory in many developing countries [34]. 
However, in Mauritius, currently it is not mandatory for food establishments to have such a HACCP or food safety management system in place. Nevertheless, some of the food businesses are voluntarily HACCP certified for reason of best practices. One of the main HACCP certification organisations in Mauritius is Société Générale de Surveillance (SGS), which has core services of inspection, testing, certification and verification [35]. Another important certification body is the Mauritius Standards Bureau (MSB) and according to its record, 8 food businesses are HACCP certified [36].

\section{Data and Statistics on Reported Foodborne Disease Cases in Mauritius}

The Health Statistics Unit (HSU) of the MOHQL has been compiling statistics on reported foodborne disease, since 1975 . However, data showed that only a few cases were documented in early years due to poor reporting system, which was improved significantly starting 1990 [37]. Reporting of foodborne disease cases is mandatory in Mauritius under section 42 of the Public Health Act 1925 (MU). Medical practitioners must report patients suffering from symptoms of foodborne diseases to the Sanitary Authority of the nearest Health Office by filling and forwarding a certificate of notification by virtue of the Public Health (Infectious or Communicable Diseases) Regulations 1987 (MU). However, the law did not specify the time frame, within which the case must be reported to the Sanitary Authority. Data in Table 1 show the number of reported food outbreaks between 1990 and 2015.

Due to the skewness of the data collected for foodborne disease cases, the medians and interquartile ranges (IQR) were calculated following the method of Rees [38]. In addition, as data were not normally distributed, nonparametric statistical analysis using Wilcoxon [39] signed rank test was used to compare incidence rates between seasons, regions, and sexes. The incidence rates (IRs) of the epidemiological data were calculated following the method of HSU [40]:

$$
\text { Incidence Rate }=\frac{\text { Number of new cases in a given year }}{\text { Mid-year population of the same year }} \times 100 \text {. }
$$

All statistical analyses were performed using Minitab $^{\circledR}$ (Minitab $^{\circledR}$, Inc., Version 17) at $95 \%$ confidence level.

\section{Common Sources of Foodborne Diseases in Mauritius}

Sprenger [14] reported that foodborne diseases occur following a chain of sequential events, including, contamination of ready-to-eat food with the causative agent, multiplication of the causative agent, and ingestion of the contaminated food. The same author indicated that sources of food contamination and possible associated diseases might include food handlers, raw food and water, insects, rodents, animals and birds, and environmental factors, such as, soil and dust. An earlier study by Bean et al. [42] summarised the main causes of foodborne diseases to include abuse of storage temperature, cooking food at temperature 
Table 1. Annually reported foodborne disease cases in Mauritius between 1990 and 2015.

\begin{tabular}{lccc}
\hline Year & Reported foodborne disease cases & Year & Reported foodborne disease cases \\
\hline 1990 & 32 & 2003 & 60 \\
1991 & 78 & 2004 & 160 \\
1992 & 27 & 2005 & 29 \\
1993 & 57 & 2006 & 78 \\
1994 & 39 & 2007 & 766 \\
1995 & 57 & 2008 & 129 \\
1996 & 13 & 2009 & 718 \\
1997 & 35 & 2010 & 156 \\
1998 & 28 & 2011 & 445 \\
1999 & 73 & 2012 & 264 \\
2000 & 62 & 2013 & 390 \\
2001 & 23 & 2014 & 143 \\
2002 & 33 & 2015 & 42 \\
\hline
\end{tabular}

Source: [40] \& [41].

lower than required, food contamination due to poor environmental and personal hygiene, and cross-contamination. During the past decades, foodborne diseases caused by bacteria, parasites, viruses and prions have been high on the agenda of policy makers, and have been given wide media coverage worldwide [43]. Mauritius is no exception and outbreaks related to microbial contamination are regularly documented by the MOHQL since 2001. However, data on foodborne diseases in developing countries, in general, are distorted by under-reporting due to the absence of strong surveillance and reporting system [32]. For example, in Mauritius, only 42 cases of foodborne diseases were notified in 2015, whereas, 76,690 people attended public health institutions for treatment due to gastroenteritis and diarrhoea of presumed infectious origin [40]. The same source reported also that during the same period 2378 patients sought medical care in the public health care centres for toxic effects of noxious foodstuff and other poisoning. These observations clearly demonstrated that it was most probable that many cases of foodborne diseases were not reported in that year.

Data in Figure 1 revealed that from 2001 to 2014 there was a clear demarcation of Salmonella spp. as major pathogens compared with Campylobacter spp. However, the incidence rate of Salmonella spp. showed continuous and significant decline between 2008 and 2012. Whereas the incidence rate (IR) of Campylobacter spp. increased between 2014 and 2015. In fact, data from 2015 showed that Campylobacter spp. with IR of 8.39 became the leading pathogens ahead of Salmonella spp. $(\mathrm{IR}=7.92)$.

These observations were in agreement with data published in the European Union, where Campylobacter spp. were the leading foodborne disease pathogens, 


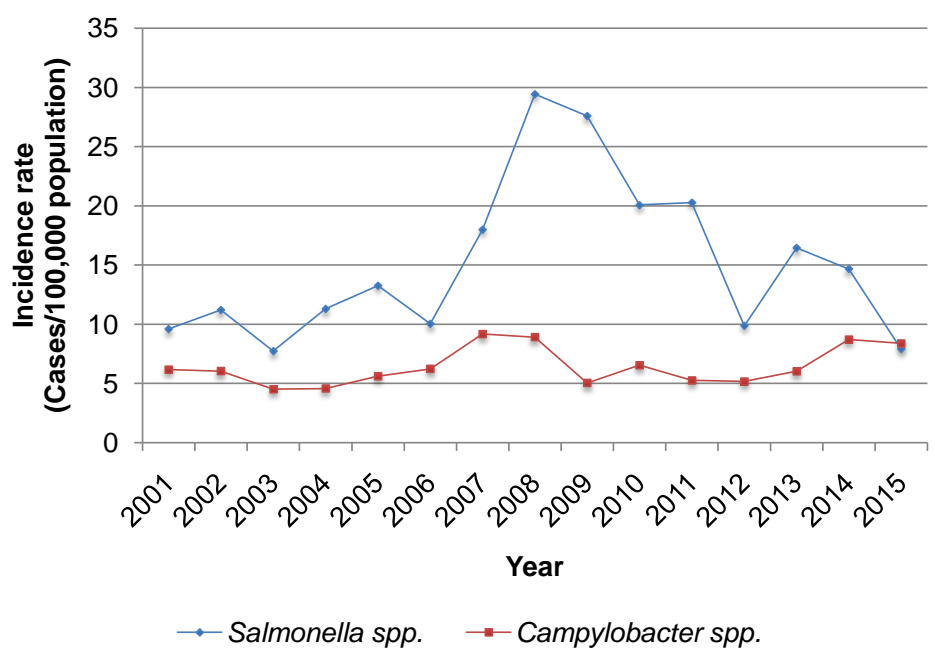

Figure 1. Incidence rate of foodborne diseases caused by Salmonella spp. and Campylobacter spp. between 2001 and 2015. Source: [40] [41] [46] [47] [48].

followed by Salmonella spp. [44]. However, Salmonella spp. were still the main foodborne disease pathogen in the USA until 2014 [45].

\subsection{Salmonellosis}

Salmonella is a genus of Gram-negative aerobic to facultative anaerobic rod usually found in the intestinal tract of animals and birds [14] [43], mainly chicken [49]. There are more than 2000 serovars, which can cause foodborne infection by ingesting a quantity of more than $10^{3} \mathrm{CFU}$, but in some virulent strain consumption of smaller number of Salmonella can cause the disease [2]. The typical symptoms of salmonellosis are severe abdominal pain, diarrhoea, nausea, vomiting and fever, with an onset usually ranging between 12 and 36 hours from ingestion of the contaminated food [50]. Egg and egg products are most often implicated in the infections [51]. In 2008, 53 cases of salmonellosis were reported in Mauritius following the consumption of food containing raw egg, namely marlin mousse, which was contaminated with Salmonella enterica serovar Typhimurium [52]. Another important outbreak occurred in Mauritius in 2011, when 172 patients reported to hospitals with foodborne disease symptoms after the consumption of pastry cakes in which a Salmonella sp. was isolated [53].

\subsection{Campylobacteriosis}

The genus Campylobacter contains 16 species, among which many can cause gastroenteritis [2]. The same authors reported that the microorganism is a Gram-negative, motile, non-sporulating and rod-shaped bacterium. Campylobacter jejuni followed by Campylobacter coli are most commonly involved in foodborne diseases [54]. Although faecal-oral route of transmission of the disease has been established, zoonotic or foodborne transmission is more common 
[4]. As reported by Man [54] many animals are reservoir of the pathogens, which are widespread in the environment. However, prevalence among chicken is highest and so handling and consumption of chicken meat represent important risks of campylobacteriosis [55]. Incubation period of Campylobacter ranges from 2 - 5 days, and the symptoms are diarrhoea, abdominal cramps and fever [56].

\section{Pattern of Incidence Rate of Foodborne Disease Cases in Mauritius}

Detailed results of the incidence rate of foodborne disease cases in Mauritius from 1990 to 1999, and 2000 to 2015 are shown in Figure 2. A comparison of the median incidence rate and interquartile ranges (IQR) of foodborne disease cases before (median: 3.28; IQR: 2.45 - 5.13) and during (median: 10.85; IQR: 3.32 21.02) the enforcement of the law (Figure 2) showed a higher incidence rate when the law was enforced in 2000. In fact, the yearly incidence rate was almost constant until 2006, whereas, from 2007 to 2013, data showed an obvious increase in foodborne disease outbreaks, with four prominent spikes in 2007, 2009, 2011 and 2013. However, data from 2014 to 2015, revealed a decreasing tendency. These findings were in agreement with those reported by Meadows, Miller \& Coustasse [57] in the USA. These authors reported that foodborne diseases were still rampant in the country after the introduction of the Food Safety Modernization Act 2010 in the USA. They attributed that to the complex methods of food production and difficulty to trace back contaminated food. In contrast with observations from the Mauritian and American studies, Gorman, Bloomfield \& Adley [58] in the Republic of Ireland, and Schmutz et al. [59] in Switzerland reported decline in salmonellosis food illnesses after the introduction of law.

\subsection{Foodborne Disease Cases by Month and Season}

\subsubsection{Month}

The medians annual incidence rates of foodborne disease cases illustrated based on the monthly distribution from 2006 to 2015 are sown in Figure 3. The highest median annual incidence rates between 2006 and 2015 occurred in the months of October (median: 1.29; IQR: 0.28 - 2.11), December (median: 1.29; IQR: $0.47-2.81$ ), and January (median: 1.26; IQR: $0.36-1.90$ ). Those months were among the warmest of the year as they were in summer. On the other hand, the lowest median annual incidence rates were in July (median: 0.24; IQR: 0.12 0.66), August (median: 0.12; IQR: $0.04-0.98$ ), and September (median: 0.16; IQR: $0.00-0.24)$ and those months were among the coolest of the year as they were in winter. Therefore, a probable reason for the frequent occurrence of foodborne disease outbreaks during the stated months could be the summer ambient temperature [60].

\subsubsection{Season}

Seasonal comparison showed that the incidence rate between summer and winter was significantly different $(\mathrm{p}<0.05)$. The highest difference was observed in 


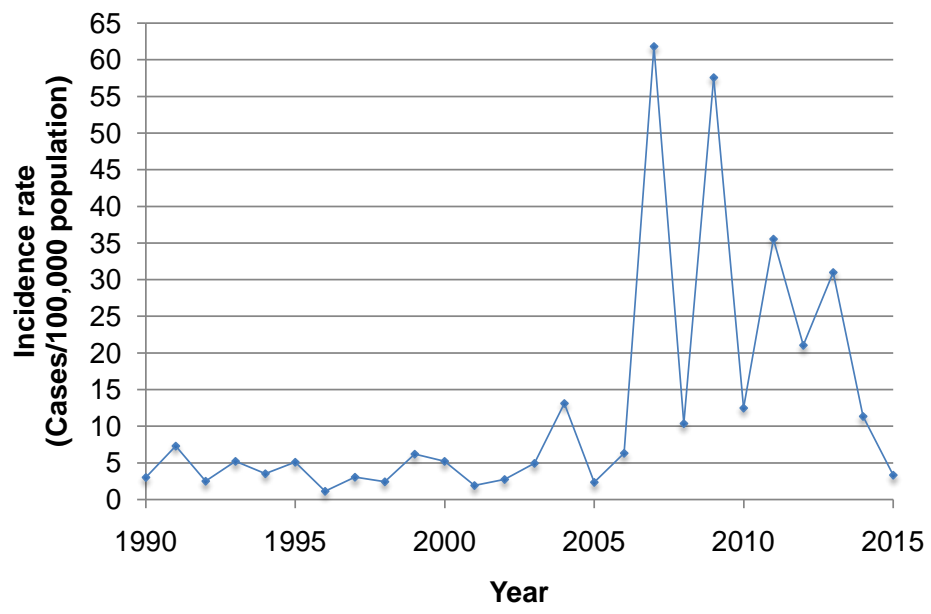

Figure 2. Incidence rate of foodborne disease cases from 1990 to 2015. Source: [40] \& [41].

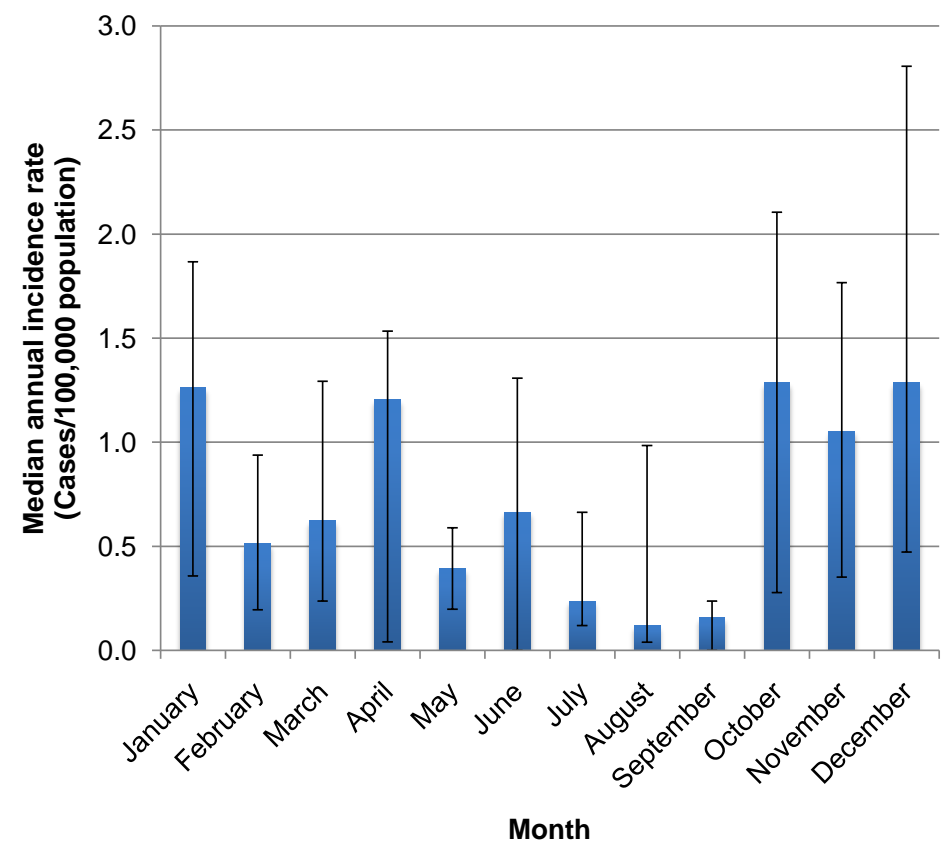

Figure 3. Median annual incidence rate of foodborne disease cases by month from 2006 to 2015 Source: [40] [41] [47] [48] [62]-[67].

$2009(\mathrm{IR}=54.65)$ followed by $2007(\mathrm{IR}=52.03)$, whereas, the lowest difference was in 2015 ( $I R=0.16)$ and $2006(I R=2.55)$ (Figure 4). These findings were in agreement with other studies, which found the highest number of Salmonella infection during summer [59] [61]. In fact, Lake et al. [60] argued that growth of pathogens, such as Salmonella spp. was positively related to temperature, within the range from $7.5^{\circ} \mathrm{C}$ to $37^{\circ} \mathrm{C}$. Actually, the average ambient temperature in Mauritius during summer could reach $30^{\circ} \mathrm{C}$ with a peak of $34.4^{\circ} \mathrm{C}$ in some localities [20]. Such conditions were described by Lake et al. [60] as favourable for the growth of most pathogens. 


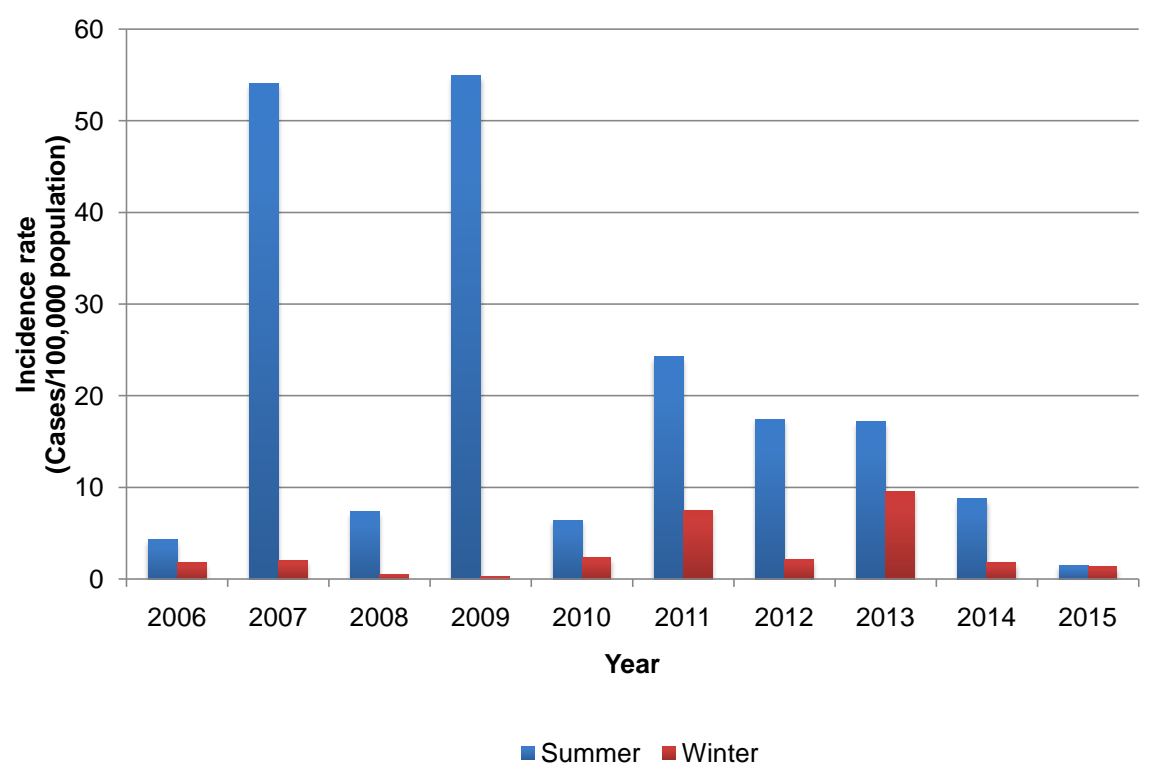

Figure 4. Incidence rate of foodborne disease cases by season from 2006 to 2015. Source: [40] [41] [47] [48] [62]-[67].

Additionally, as suggested by Kim et al. [61], the high rate of the foodborne diseases during summer could also be attributed to large social gatherings and activities, which were favoured by the weather conditions. In fact, in Mauritius, summer coincides with the end of December festivities and school holidays and known for its common social gatherings. Furthermore, consumption of raw fruits and salad, and barbecues were common practice during that period in Mauritius, which may increase the risk of foodborne illnesses [60].

\subsection{Incidence Rate of Foodborne Disease Cases by District and Region}

\subsubsection{District}

The distribution of annual incidence rate of foodborne disease cases between 2006 and 2015 among various districts in Mauritius is presented in Figure 5. Data showed that the highest median annual incidence rate occurred in Flacq (median: 4.81; IQR: 0.86 - 11.53), followed by Grand Port (median: 2.00; IQR: 0.67 - 4.64) and Plaine Wilhems (median: 1.74; IQR: 1.11 - 3.10). Black River (median: 0.04; IQR: 0.00 - 0.47), Rodrigues (median: 0.12; IQR: 0.00 - 0.62) and Moka (median: 0.23; IQR: $0.00-0.47)$ showed the lowest median annual incidence rate.

\subsubsection{Region}

Regional comparison (Figure 6) revealed that the incidence rate in rural regions was significantly $(\mathrm{p}<0.05)$ greater than in urban regions. Since the rural to urban population ratio was only 3:2 [19] a probable explanation for the higher incidence of foodborne disease cases in rural regions could be that most of the rural regions are located in the warmest part of the country. 


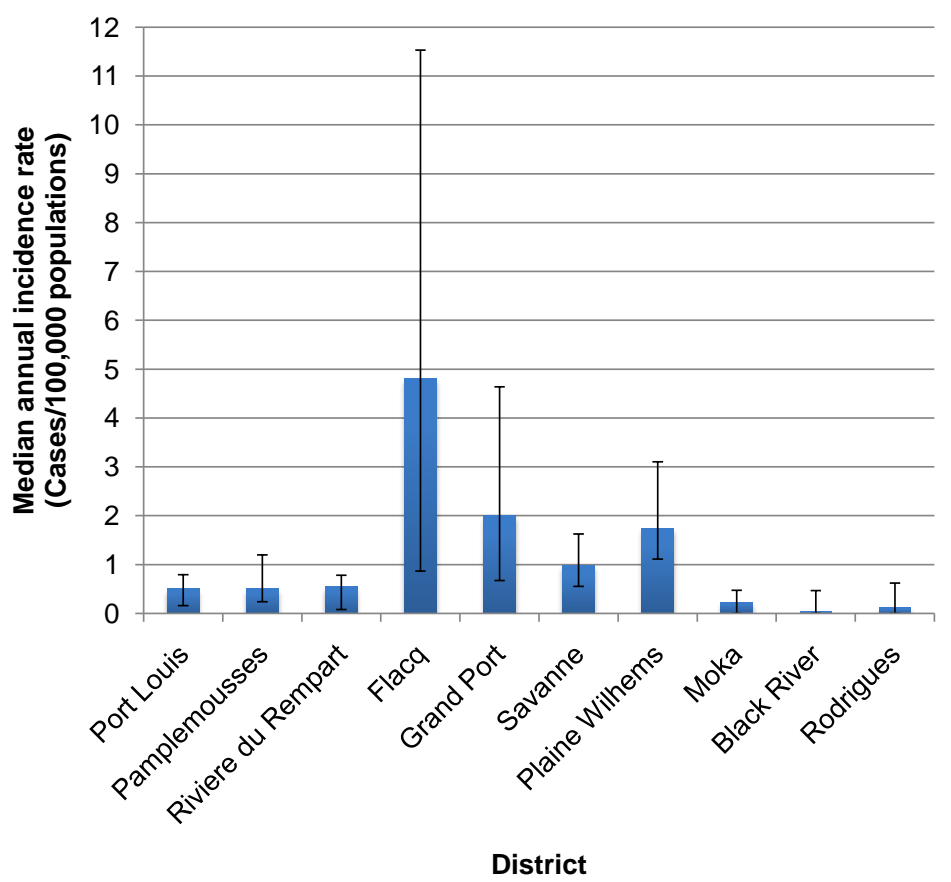

Figure 5. Median annual incidence rate of foodborne disease cases by district from 2006 to 2015. Source: [40] [41] [47] [48] [62]-[67].

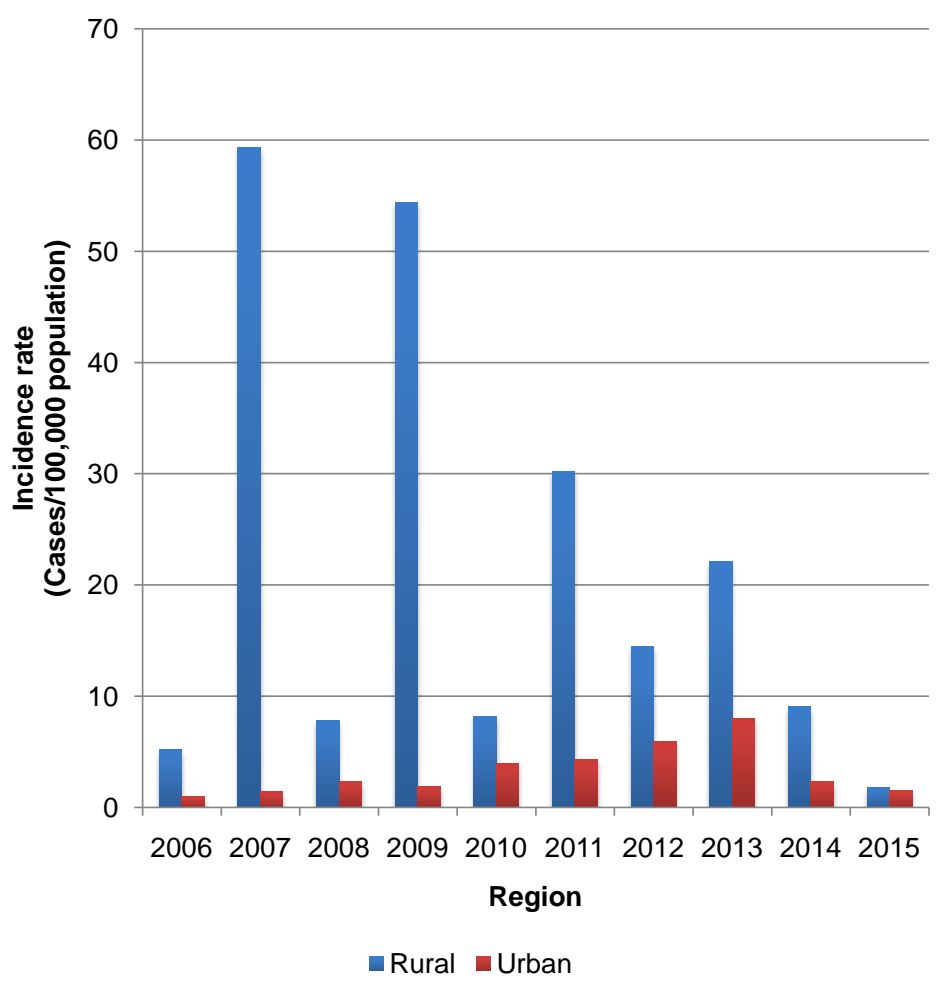

Figure 6. Incidence rate of foodborne disease cases by region from 2006 to 2015. Source: [40] [41] [47] [48] [62]-[67].

These findings contradicted with the observations reported by Schielke, Rosner \& Stark [68], who indicated a higher incidence rate of foodborne diseases 
in urban rather than rural regions in Germany. Such variations and contradictions in conclusions of different studies could be related to the fact that the status of living of people and food services in rural-urban regions of Mauritius are different from other countries. The living standard of some Mauritian people in some urban areas is lower than in rural.

\subsection{Incidence Rate of Foodborne Disease Cases by Age and Sex}

\subsubsection{Age}

The median annual incidence rate of foodborne disease cases for the different categories of age groups was distributed within each year from 2006 to 2015 (Figure 7). The age group 10 to 19 years old (median: 4.39; IQR: 1.07 - 8.06) was the most significantly vulnerable groups to foodborne diseases $(p<0.05)$. A possible explanation could be the popularity of the food mostly linked to foodborne diseases among that age group [69] [70]. On the other hand, the age group of 60 years old and over was the least affected, suggesting that old people in Mauritius might have been more careful in selecting and eating their food.

However, the international trends showed that $40 \%$ of foodborne disease cases were among children of less than 5 years old [71]. For instance, a study in Germany found the majority of food borne diseases was among children of less than 5 years old [59].

\subsubsection{Sex}

Results from this review demonstrated that the number of reported cases of food borne diseases among Mauritian male and female (Figure 8) were not significantly different $(\mathrm{p}>0.05)$. However, the reported cases were greater among females than male in the years 2011, 2013 and 2015. In contrast, a study in the Switzerland revealed that Campylobacter case notifications were more frequent in males than females in all but 20 - 24 year-olds [59]. Similarly, another study in Germany found that campylobacteriosis was higher among male, except for age group of 20 - 29 years, where the incidence among female was higher [68]. The same authors argued that women in that age group were more exposed as they were more frequently involved in meal preparation with potentially contaminated chicken.

\section{Strengths and Weaknesses in Mauritian Food Legislation}

The strengths and weaknesses of the Mauritian Food Act 1998 (Ministry of Health and Quality of Life) [72], and Food Regulations 1999 (Ministry of Health and Quality of Life) [73], were identified and summarised in Table 2.

Abuse of storage temperature was controlled under the Mauritius Food Regulations 1999 (73) to ensure that food was kept at the right temperature, (chill: 1 to $8^{\circ} \mathrm{C}$; frozen: $-18^{\circ} \mathrm{C}$ or below). However, according to the law, chill food might be kept between $5^{\circ} \mathrm{C}$ and $8^{\circ} \mathrm{C}$. Additionally, the Mauritian food law did not provide recommended storage conditions of warm foods. The Mauritian law provided some information on personal hygiene standards, as well, as training 


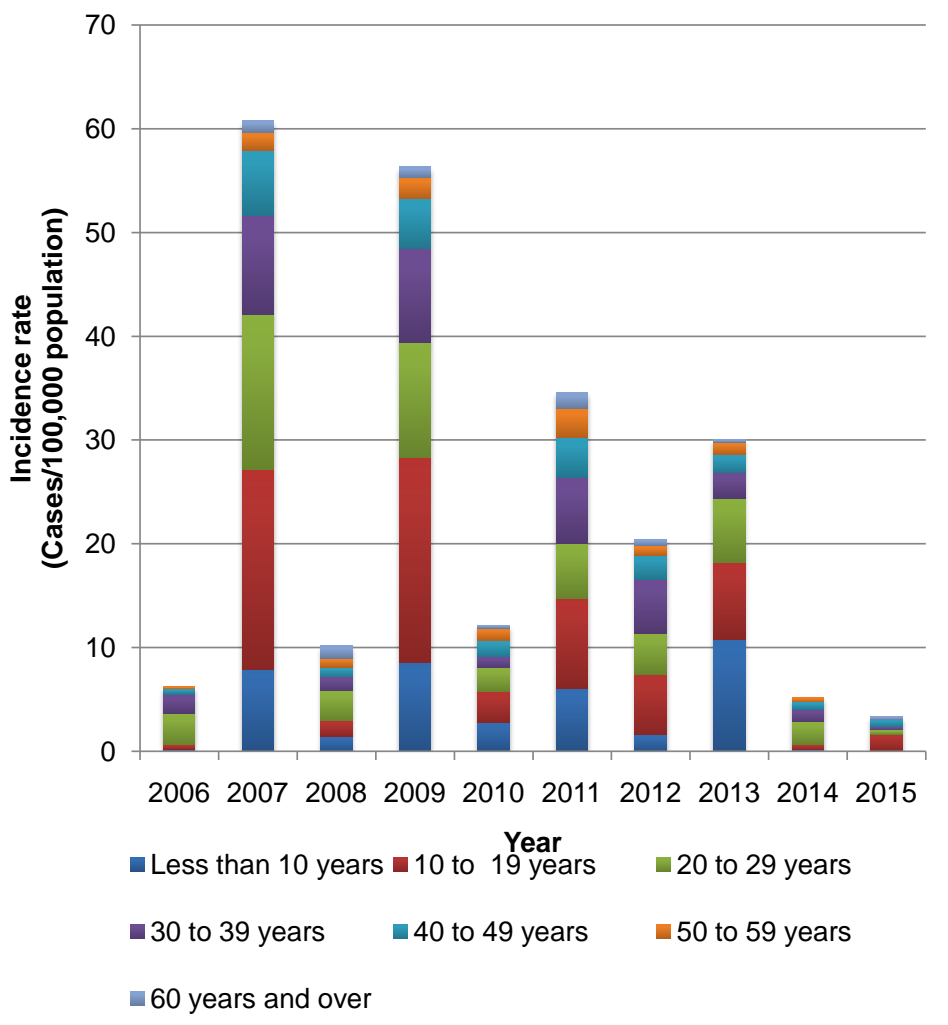

Figure 7. Incidence rate of foodborne disease cases by age group from 2006 to 2015. Source: [40] [41] [47] [48] [62]-[67].

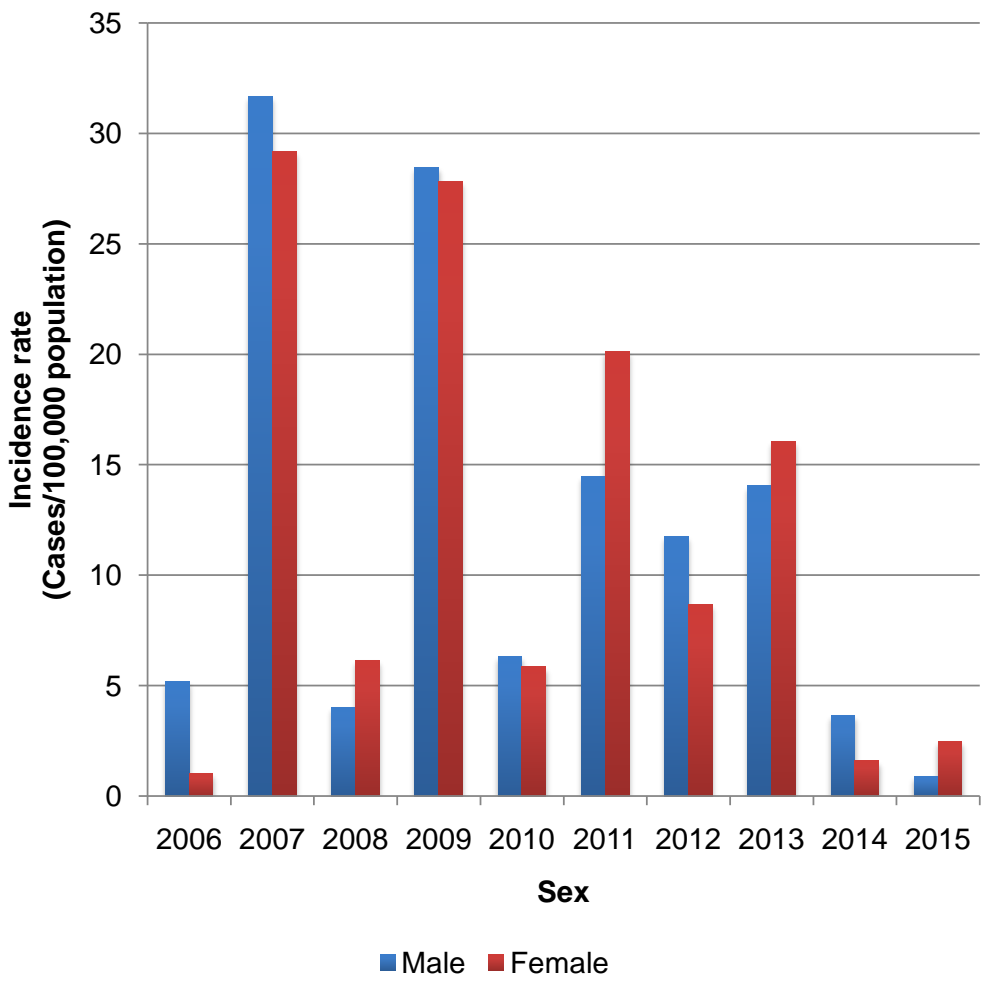

Figure 8. Incidence rate of foodborne disease cases by sex from 2006 to 2015. Source: [40] [41] [47] [48] [62]-[67]. 
Table 2. Summary of strengths and weaknesses in Mauritian food legislation.

\begin{tabular}{|c|c|c|}
\hline & Strength & Weakness \\
\hline \multirow[t]{2}{*}{$\begin{array}{l}\text { Abuse of storage } \\
\text { temperature }\end{array}$} & $\begin{array}{l}\text { Provided temperatures at which chill } \\
\left(1^{\circ} \mathrm{C} \text { to } 8^{\circ} \mathrm{C}\right) \text { and frozen }\left(-18^{\circ} \mathrm{C} \text { or }\right. \\
\text { below }) \text { food should be kept. }\end{array}$ & $\begin{array}{l}\text { No provision of the temperature } \\
\text { at which warm food should } \\
\text { be kept. }\end{array}$ \\
\hline & & $\begin{array}{l}\text { Allowed chilled food to be kept } \\
\text { between } 5^{\circ} \mathrm{C} \text { and } 8^{\circ} \mathrm{C} \text {. }\end{array}$ \\
\hline \multirow[t]{2}{*}{ Personal hygiene } & $\begin{array}{l}\text { Provided personal hygiene } \\
\text { standards for food handlers. }\end{array}$ & \\
\hline & $\begin{array}{l}\text { Food handlers should undergo } \\
\text { training and medical screening } \\
\text { prior to starting to handle food. }\end{array}$ & $\begin{array}{l}\text { Training of food handlers was } \\
\text { neither continuous nor assessed, } \\
\text { and was not targeted. }\end{array}$ \\
\hline Undercooking & & $\begin{array}{l}\text { The law was silent on the } \\
\text { minimum temperature/time } \\
\text { combination at which food of } \\
\text { animal origin must be cooked. }\end{array}$ \\
\hline Cross-contamination & $\begin{array}{l}\text { Stipulated measures, at all levels, to } \\
\text { prevent cross-contamination. }\end{array}$ & $\begin{array}{l}\text { Measures were mainly } \\
\text { prescriptive, without any } \\
\text { risk-based method of food } \\
\text { safety management. }\end{array}$ \\
\hline \multirow[t]{2}{*}{ Unsafe sources of food } & $\begin{array}{l}\text { Extensive provisions, such as, } \\
\text { traceability, sampling and testing } \\
\text { to ensure safety of food sources. }\end{array}$ & $\begin{array}{l}\text { Safety of food was based on end } \\
\text { product assessment, sampling } \\
\text { and conventional testing. }\end{array}$ \\
\hline & & $\begin{array}{l}\text { No explicit provision for } \\
\text { field-testing methods. }\end{array}$ \\
\hline
\end{tabular}

Source: [69].

and medical screening for food handlers. But the model of training was incomplete, as it was neither continuous nor assessed regularly.

No minimum temperature/time combination was provided in the law to ensure that food, particularly of animal origin, was adequately cooked to ensure its safety.

The Mauritian law did make provisions to compel food operators to take adequate measures, at all levels, to prevent contamination. However, it was not mandatory for them to have a risk-based method of food safety management system in place.

The Mauritian Food Act [72] and Food Regulations 1999 [73], had a wide range of provisions, such as, traceability, sampling and testing to ensure that food was not obtained from unsafe sources. The drawback of the law was that it relied mainly on end product assessment, sampling and testing by conventional methods. In addition, PHFSIs were not empowered to use field-testing equipment to verify the safety of food during site visits.

\section{Evaluation of Enforcement of the Current Mauritian Food Legislation and Its Impact on Human Safety}

The percentage changes in the number of inspections and contraventions from 2006 to 2015 compared to those of 2005 are shown in Table 3. Data revealed the 
Table 3. Percentage change in enforcement and contravention activities from 2006 to 2015 relative to 2005 .

\begin{tabular}{ccc}
\hline Year & $\begin{array}{c}\text { \% Change in the number of inspections } \\
\text { relative to 2005 }\end{array}$ & $\begin{array}{c}\text { \% Change in the number of } \\
\text { contraventions relative to } 2005\end{array}$ \\
\hline 2006 & $-37.34 \%$ & $-81.95 \%$ \\
2007 & $-38.97 \%$ & $-65.39 \%$ \\
2008 & $+6.58 \%$ & $+12.74 \%$ \\
2009 & $+38.25 \%$ & $+9.13 \%$ \\
2010 & $+0.47 \%$ & $+21.23 \%$ \\
2011 & $+40.19 \%$ & $+88.44 \%$ \\
2012 & $+44.53 \%$ & $+70.40 \%$ \\
2013 & $+30.03 \%$ & $+20.67 \%$ \\
2014 & $-19.44 \%$ & $-30.82 \%$ \\
2015 & $-14.52 \%$ & $-50.09 \%$ \\
\hline
\end{tabular}

Source: [40] [47] [67].

highest \% increase in inspection $(+44.53 \%)$ and in contravention $(+88.44 \%)$ were in 2012 and 2011, respectively. However, the higher number of inspections carried out by the Public Health and Food Safety Inspectors (PHFSIs) (+6.58\%, $+38.25 \%,+0.47 \%,+40.19 \%,+44.53 \%,+30.03 \%)$, as well as, contraventions established $(+12.74 \%,+9.13 \%,+21.23 \%,+88.44 \%,+70.40 \%,+20.67 \%)$ during that period did not prevent the occurrence of major foodborne disease outbreaks in Mauritius. These observations were in agreement with Olsen et al. [74] who reported a similar finding. It was argued that the main limitation of enforcement activities was that the action favouring the occurrence of an outbreak might occur outside the inspection time [16]. In other words, 'snap-shot' inspections were considered as ineffective in detecting potential risk of foodborne diseases [75]. In contrast, studies by Gorman, Bloomfield \& Adley [58] and Schmutz et al. [59] showed an improvement in food safety upon the enforcement of food inspection.

The significant drop in the number of inspection and contraventions in Mauritius in 2006, 2007, 2014 and 2015 was due to the outbreaks of the epidemics of chikungunya fever and dengue fever. During these years all resources were mainly concentrated on eliminating the diseases, with less attention on inspection [76] [77] [78].

Another factor contributed to the loose inspection in these years was related to the additional responsibility of the HIU to enforce other legislations, such as, the Public Health Act 1925 (MU) [79]. Consequently, food safety activities were sacrificed during the epidemics, as PHFSIs were called to prioritise enforcement of public health measures to eliminate the diseases. Therefore, performing these two enforcement activities concurrently could have hindered the effectiveness of the PHFSIs in maintaining inspections and contraventions related to food safety 
on the field. However, regular enforcement of the food law was essential in compelling food operators to comply with food safety practices to reduce the risk of foodborne diseases [69].

\section{Strengths and Weaknesses of the Current Mauritian Food Law in Comparison with the Australian Food Law}

Analysis of the Mauritian food law (Table 2) showed several strengths and weaknesses in addressing foodborne diseases. The Food Regulations 1999 (MU) [73] made several provisions to ensure that foods, whether ready-to-eat or raw, were kept at the right temperature. These sections of the law aimed at protecting the consumer from the risk of food with high level of pathogens or toxins. In fact, it was argued that respecting the temperature requirements of food was essential to prevent foodborne diseases, in particular, toxin based outbreaks [80]. However, the Mauritian legislation only specified temperatures for chilled and frozen food, but not for food which had to be maintained warm. In contrast, the Australia New Zealand Food Standards Code, 2003) [81] specified both ranges of temperatures at which such food should be kept. For instance, the Australian legislation emphasised that food in which growth of pathogenic microorganisms and/or formation of toxins might occur must either be kept at $5^{\circ} \mathrm{C}$, or below, or $60^{\circ} \mathrm{C}$, or above, depending on its nature. The Mauritian legislation also allowed low temperature food to be kept between $5^{\circ} \mathrm{C}$, and $8^{\circ} \mathrm{C}$, whereas, in the Australian law the maximum low temperature was $5^{\circ} \mathrm{C}$. Keeping food above $5^{\circ} \mathrm{C}$, can be hazardous as psychrotrophic pathogens, such as, L. monocytogenes grow rapidly at $7^{\circ} \mathrm{C}[2]$. Therefore, it is safer to keep refrigerated foods at temperature $5^{\circ} \mathrm{C}$, or below.

Another aspect of the Mauritian food legislation pertained to personal hygiene of people handling food. According to Greig et al. [82] poor personal hygiene of infected food handlers increased the risk of foodborne diseases. The Food Regulations in Mauritius (Ministry of Health and Quality of Life, 1999) [73] listed the required standards for personal hygiene of people engaged at any stage of food handling. In addition, it was also mandatory under the same legislation for food handlers to be trained in food hygiene and medically screened. In fact, training of food handlers has been shown to improve food safety and, consequently, reduced the risk of foodborne diseases [83] [84]. However, the model specified in the Mauritian law was incomplete as there was no provision for continuous education of food handlers, which was claimed to improve food safety practices [85]. Furthermore, the knowledge gained during the training was not subjected to an assessment, which was essential to ensure its effectiveness [86]. Moreover, the content of the Mauritian model of food handlers training course was the same for all food handlers, whether they were involved in high or low risk foods. Such practice was in disagreement with the recommendation that food safety training course should be tailor-made [69]. On the other hand, the Australian Food Act in Victoria, 1984 [87] also had a similar provision where food handlers must undergo a Quality Assurance Safety Program prior to starting their activi- 
ty. However, medical screening was not a requirement under the Australian law.

Regarding cooking temperature and time of food from animal sources, the Mauritian food legislation did not make any provision for the minimum temperature and time at which such type of food should be cooked. In comparison, the Australia New Zealand Food Standards Code, 2003 [81] did compel food businesses to ensure that food was cooked using validated method to guarantee the microbiological safety. However, no temperature/time combination was specified in the Australian law.

The Mauritian legislation did cater for risk of cross-contamination, whether microbiological, chemical or physical hazards. In fact, cross-contamination regarding microbiological hazards had been shown to be an important cause of foodborne diseases [88] [89]. The Mauritian Food Regulations (Ministry of Health and Quality of Life, 1999) [73] provided standards, at all levels of productions, including the structure of the building, the flow of the process, food handling as well as storage in order to reduce food cross-contamination. However, the law was mainly prescriptive, relying essentially on "snap-shot" inspections for the identification of deviations [75]. Additionally, the current Mauritian food law did not contain a risk-based method for food safety management system, such as, the HACCP. On the other hand the Food Act 1984, Victoria [87] did require the proprietor of a food business to have a food safety program with the objective to systematically deal with hazards, including those arising from cross-contamination. The benefit of such a system had been shown to reduce foodborne diseases [32].

The Mauritian food legislation made extensive provisions to protect the consumer from unsafe sources of food. Those provisions varied from traceability of food products, microbiological, chemical and physical standards, to procedures for sampling and testing the levels of contaminants. In comparison, Food Act in Victoria, 1984 [87] and the Australia New Zealand Food Standards Code, 2003 [78] had similar provisions regarding unsafe food, but coupled with mandatory in-house Food Safety Programs for food businesses. Consequently, the provisions in the Mauritian law were inadequate in their objectives of ensuring safe food on the market. For instance, sampling and testing were known to be limited in their effectiveness in removing unsafe food from the food chain [16]. The author argued that some of the shortcomings were sample size, unavailability of tests or tests are not regularly performed, limitations of conventional methods of analysis and the time it took to obtain results. In order to address some of those shortcomings, rapid testing of food could be an alternative solution [90]. Therefore, including rapid test methods in the Mauritian food legislation, in particular, at field level could be a major step in ensuring safe food to the consumers and ultimately reducing the risk of foodborne diseases.

\section{Recommendations}

This thorough review of the Mauritian food law suggests that the following recommendations are essential in order to improve the current food legislation. It is anticipated that enforcement of the following recommendations will reduce 
the incidence of foodborne diseases and improve human safety:

- the Mauritian food law must be revised from being prescriptive and include risk assessments;

- the law must include a clause to compel medical practitioners to inform the Sanitary Authority, as soon as possible, preferably within 48 hours, of a suspected case of foodborne disease;

- legal provision must be provided for storage of chilled food at $5^{\circ} \mathrm{C}$ or below and warm food at $60^{\circ} \mathrm{C}$ or above;

- the model of food handlers training provided in the law must include a targeted approach, as well as, a provision for assessment and continuous education;

- the law must specify the minimum time/temperature combination for cooking raw food, particularly, of animal sources;

- enforcement activities must be enhanced during the summer season;

- enforcement activities in rural areas must have a higher consideration; and

- the use of field-testing equipment to assess food contamination on site must be included in the law.

\section{Conclusions}

The aim of this study was to evaluate the impact of the food legislation in Mauritius on the pattern of foodborne diseases in the country over the past 16 years and its suitability in recent years. Results from this review confirmed that overall foodborne diseases increased in spite of the enactment and enforcement of the Food Act 1998 (MU) [72] and Food Regulations 1999 (MU) [73]. In addition, enforcement activities have been found to be consistent over the period investigated, except during epidemics of chikungunya fever and dengue fever. Furthermore, review of the current Mauritian food legislation highlighted several strengths, as well as, weaknesses of the law in reducing the risk of foodborne diseases. Moreover, comparison of the Mauritian to the Australian food law revealed some similarities, as well as, differences between the two legislations in ensuring food safety. Therefore, the Mauritian food legislation and its enforcement need to be revised, in order to make them more effective in their objective, which is the prevention of foodborne diseases.

There might be some specific factors, which might have contributed to the increase in the number of foodborne illnesses in Mauritius, such as, sacrificing food safety activities during epidemics of chikungunya fever and dengue fever. Therefore, future studies might focus on establishing if there is any relation between the decrease in enforcement activities during epidemics and outbreaks of foodborne diseases. For example, studies might investigate into any impact of the drastic drop in inspections and contraventions in 2006 and 2007 and the spike in foodborne disease cases in 2007.

\section{References}

[1] WHO (2007) World Health Organisation: WHO Initiative to Estimate the Global 
Burden of Foodborne Diseases. First Formal Meeting of the Foodborne Disease Burden Epidemiology Reference Group (FERG), Geneva, 26-28 November 2007.

[2] Ray, B. and Bhunia, A.K. (2014) Fundamental Food Microbiology. 5th Edition, CRC Press, Boca Raton.

[3] Hanson, L.A., Zahn, E.A., Wild, S.R., Dopfer, D., Scott, J. and Stein, C. (2012) Estimating Global Mortality from Potentially Foodborne Diseases: An Analysis Using Vital Registration Data. Population Health Metrics, 10, 1-7. https://doi.org/10.1186/1478-7954-10-5

[4] Scallan, E., Hoekstra, R.M., Angulo, F.J., Tauxe, R.V., Widdowson, M.A., Roy, S.L., Jones, J.L. and Griffin, P.M. (2011) Foodborne Illness Acquired in the United States -Major Pathogens. Emerging Infectious Diseases, 17, 7-15. https://doi.org/10.3201/eid1701.P11101

[5] Kuchenmueller, T., Abela-Ridder, B., Corrigan, T. and Tritscher, A. (2013) World Health Organization Initiative to Estimate the Global Burden of Foodborne Diseases. Revue Scientifique et Technique Office International des Epizooties, 32, 459-467.

[6] WHO (2008) World Health Organisation: The Global Burden of Disease. HO, Geneva.

[7] Kuchenmueller, T., Hird, S., Stein, C., Kramarz, P., Nanda, A. and Havelaar, A.H. (2009) Estimating the Global Burden of Foodborne Diseases-A Collaborative Effort. Eurosurveillance, 14, 1-4. https://doi.org/10.2807/ese.14.18.19195-en

[8] Tariq, L., Haagsma, J. and Havelaar, A. (2011) Cost of Illness and Disease Burden in The Netherlands Due to Infections with Shiga Toxin-Producing Escherichia coli O157. Journal of Food Protection, 74, 545-552. https://doi.org/10.4315/0362-028X.JFP-10-252

[9] Nyachuba, D.G. (2010) Foodborne Illness: Is It on the Rise? Nutrition Reviews, 68, 257-269. https://doi.org/10.1111/j.1753-4887.2010.00286.x

[10] Lindqvist, R., Andersson, Y., Toljander, J., Ivarsson, S. and Dovärn, A. (2012) Public Health Burden Due to Infections by Verocytotoxin-Producing Escherichia coli (VTEC) and Campylobacter spp. as Estimated by Cost of Illness and Different Approaches to Model Disability-Adjusted Life Years. Scandinavian Journal of Public Health, 40, 294-302. https://doi.org/10.1177/1403494811435495

[11] Abelson, P., Forbes, M.P. and Hall, G. (2006) The Annual Cost of Foodborne Illness in Australia. Australian Government Department of Health and Ageing, Canberra.

[12] Lake, R., Cressey, P.J., Campbell, D.M. and Oakley, E. (2010) Risk Ranking for Foodborne Microbial Hazards in New Zealand: Burden of Disease Estimates. Risk Analysis, 30, 743-752. https://doi.org/10.1111/j.1539-6924.2009.01269.x

[13] Shin, H., Lee, S., Kim, J.S., Kim, J. and Han, K.H. (2010) Socioeconomic Costs of Foodborne Disease Using the Cost-of-Illness Model: Applying the QALY Method. Journal of Preventive Medicine and Public Health, 43, 352-361. https://doi.org/10.3961/jpmph.2010.43.4.352

[14] Sprenger, R.A. (2009) Hygiene for Management. 15th Edition, Highfield, Doncaster.

[15] Benedict, J. (2011) Poisoned: The True Story of the Deadly E. coli Outbreak that Changed the Way Americans Eat. Mariner Publishing, Buena Vista.

[16] Bryan, F.L. (2002) Where We Are in Retail Food Safety, How We Got Where We Are, and How Do We Get There? Journal of Environmental Health, 65, 29-36.

[17] NESC (2010) National Economic and Social Council: An Investigation into Food Safety in Mauritius-Recommendations for a Policy Review. NESC, Port Louis.

[18] FSANZ (2014) Food Standards Australia New Zealand: Annual Report 2013-2014. 
Food Standards Australia New Zealand, Canberra.

[19] Statistics Mauritius (2015) Statistics Mauritius: Mauritius in Figures 2014. Ministry of Finance and Economic Development, Port Louis. http://statsmauritius.govmu.org/English/Pages/default.aspx

[20] Mauritius Meteorological Services (2016) Mauritius Meteorological Services: Climate of Mauritius. http://metservice.intnet.mu/climate-services/climate-of-mauritius.php

[21] Griffith, C.J. (2006) Food Safety: Where from and Where to? British Food Journal, 108, 6-15. https://doi.org/10.1108/00070700610637599

[22] WHO (2006) World Health Organisation: Five Keys to Safer Food Manual. WHO, Geneva.

[23] Drew, C.A. and Clydesdale, F.M. (2015) New Food Safety Law: Effectiveness on the Ground. Critical Reviews in Food Science and Nutrition, 55, 689-700. https://doi.org/10.1080/10408398.2011.654368

[24] GM (2012) Government of Mauritius: Government Programme 2012-2015: Moving the Nation Forward. Republic of Mauritius, Port Louis.

[25] Jacob, C., Mathiasen, L. and Powell, D. (2010) Review: Designing Effective Messages for Microbial Food Safety Hazards. Food Control, 21, 1-6. https://doi.org/10.1016/j.foodcont.2009.04.011

[26] Powell, D.A., Jacob, C.J. and Chapman, B.J. (2011) Enhancing Food Safety Culture to Reduce Rates of Foodborne Illness. Food Control, 22, 817-822. https://doi.org/10.1016/j.foodcont.2010.12.009

[27] Yiannas, F. (2009) Food Safety Culture: Creating a Behavior-Based Food Safety Management System. Springer Science, New York. https://doi.org/10.1007/978-0-387-72867-4

[28] Griffith, C.J., Livesey, K.M. and Clayton, D. (2010) The Assessment of Food Safety Culture. British Food Journal, 112, 439-456. https://doi.org/10.1108/00070701011034448

[29] Stannard, C. (1997) Development and Use of Microbiological Criteria for Foods. Food Science \& Technology Today, 11, 137-177.

[30] FAO (1998) Food and Agricultural Organisation: Food Quality and Safety Systems : A Training Manual on Food Hygiene and the Hazard Analysis and Critical Control Point (HACCP) System. FAO, Rome.

[31] El-Hofi, M., El-Tanboly, E.S. and Ismail, A. (2010) Implementation of the Hazard Analysis Critical Control Point (HACCP) System to UF White Cheese Production Line. Internet Journal of Food Safety, 9, 331-342. https://doi.org/10.1016/j.foodcont.2010.10.013

[32] Al-Kandari, D. and Jukes, D.J. (2011) Incorporating HACCP into National Food Control Systems-Analyzing Progress in the United Arab Emirates. Food Control, 22, 851-861.

[33] Unnevehr, L.J. and Jensen, H.H. (1999) The Economic Implications of Using HACCP as a Food Safety Regulatory Standard. Food Policy, 24, 625-635. https://doi.org/10.1016/S0306-9192(99)00074-3

[34] Karaman, A.D. (2012) Food Safety Practices and Knowledge among Turkish Dairy Businesses in Different Capacities. Food Control, 26, 125-132. https://doi.org/10.1016/j.foodcont.2012.01.012

[35] SGS (2016) Société Générale de Surveillance: SGS in Brief. http://www.sgs.com/en/Our-Company/About-SGS/SGS-in-Brief.aspx 
[36] MSB (2016) Mauritius Standards Bureau: National Food Safety Management System Certification Scheme (MS 133). http://msb.intnet.mu/English/CertificationSchemes/Pages/HACCP---MS133.aspx

[37] Jeeanody, N. (2016) Chief Health Statistician, Health Statistics Unit. Atchia Building, Port Louis.

[38] Rees, D.G. (2001) Essential Statistics. 4th Edition, Chapman \& Hall/CRC, Boca Raton.

[39] Wilcoxon, F. (1945) Individual Comparisons by Ranking Methods. Biometrics Bulletin, 1, 80-83. https://doi.org/10.2307/3001968

[40] HSU (2016) Health Statistics Unit: Health Statistics Report 2015. Ministry of Health and Quality of Life, Port Louis. http://health.govmu.org/English/Pages/default.aspx

[41] HSU (2007) Health Statistics Unit: Health Statistics Report 2006. Ministry of Health and Quality of Life, Port Louis. http://health.govmu.org/English/Pages/default.aspx

[42] Bean, N.H., Griffin, P.M., Goulding, J.S. and Ivey, C.B. (1990) Foodborne Disease Outbreaks, 5-Year Summary, 1983-1987. Journal of Food Protection, 53, 711-728. https://doi.org/10.4315/0362-028X-53.8.711

[43] Newell, D.G., Koopmans, M., Verhoef, L., Duizer, E., Aidara-Kane, A., Sprong, H., Opsteegh, M., Langelaar, M., Threfall, J., Scheutz, F., Giessen, J.V.D. and Kruse, H. (2010) Foodborne Diseases-The Challenges of 20 Years Ago Still Persist While New Ones Continue to Emerge. International Journal of Food Microbiology, 139, S3-S15. https://doi.org/10.1016/j.ijfoodmicro.2010.01.021

[44] EFSA (2015) The European Union Summary Report on Trends and Sources of Zoonoses, Zoonotic Agents and Foodborne Outbreaks in 2013. European Food Safety Authority Journal, 13, 1-165.

[45] CDC (2014) Centers for Disease Control and Prevention: Estimates of Foodborne Illness in the United States. http://www.cdc.gov/foodborneburden/2011-foodborne-estimates.html

[46] HSU (2004) Health Statistics Unit: Health Statistics Report 2003. Ministry of Health and Quality of Life, Port Louis. http://health.govmu.org/English/Pages/default.aspx

[47] HSU (2010) Health Statistics Unit: Health Statistics Report 2009. Ministry of Health and Quality of Life, Port Louis. http://health.govmu.org/English/Pages/default.aspx

[48] HSU (2013) Health Statistics Unit: Health Statistics Report 2012. Ministry of Health and Quality of Life, Port Louis. http://health.govmu.org/English/Pages/default.aspx

[49] Gantois, I., Ducatelle, R., Pasmans, F., Haesebrouck, F., Gast, R., Humphrey, T.J. and Van Immerseel, F. (2009) Mechanisms of Egg Contamination by Salmonella Enteritidis. Federation of European Microbiological Societies Microbiology Reviews, 33, 718-738.

[50] WHO (2013) World Health Organisation: Salmonella (Non-Typhoidal) Fact Sheet No 139. http://www.who.int/mediacentre/factsheets/fs139/en/

[51] Braden, C.R. (2006) Salmonella enterica Serotype Enteritidis and Eggs: A National Epidemic in the United States. Clinical Infectious Diseases, 43, 512-517. https://doi.org/10.1086/505973

[52] Issack, M.I., Hendriksen, R.S., Phimy Lan Keng, L. and Lutchun, R.K.S. (2009) Sal- 
monella enterica Serovar Typhimurium in Mauritius Linked to Consumption of Marlin Mousse. Foodborne Pathogens and Disease, 6, 739-741. https://doi.org/10.1089/fpd.2009.0283

[53] National Assembly (2011) National Assembly: Fifth National Assembly Parliamentary Debate. Government of Mauriitius, Port Louis. http://mauritiusassembly.govmu.org/English/Pages/default.aspx

[54] Man, S.M. (2011) The Clinical Importance of Emerging Campylobacter Species. Nature Reviews Gastroenterology \& Hepatology, 8, 669-685. https://doi.org/10.1038/nrgastro.2011.191

[55] Dasti, J.I., Tareen, A.M., Lugert, R., Zautner, A.E. and Gross, U. (2010) Campylobacter jejuni: A Brief Overview on Pathogenicity-Associated Factors and Disease-Mediating Mechanisms. International Journal of Medical Microbiology, 300, 205-211. https://doi.org/10.1016/j.ijmm.2009.07.002

[56] Butzler, J.P. (2004) Campylobacter, from Obscurity to Celebrity. Clinical Microbiology \& Infection, 10, 868-876. https://doi.org/10.1111/j.1469-0691.2004.00983.x

[57] Meadows, P., Miller, B. and Coustasse, A. (2014) Surveillance of Foodborne Illness in the United States. Insights to a Changing World Journal, 2014, 97-107.

[58] Gorman, R., Bloomfield, S. and Adley, C.C. (2002) A Study of Cross-Contamination of Foodborne Pathogens in the Domestic Kitchen in the Republic of Ireland. International Journal of Food Microbiology, 76, 143-150. https://doi.org/10.1016/S0168-1605(02)00028-4

[59] Schmutz, C., Mausezahl, D., Jost, M., Baumgartner, A. and Mausezahl-Feuz, M. (2016) Inverse Trends of Campylobacter and Salmonella in Swiss Surveillance Data, 1988-2013. Eurosurveillance, 21, 1-9. https://doi.org/10.2807/1560-7917.ES.2016.21.6.30130

[60] Lake, R., Gillespie, I.A., Bentham, G., Nichols, G.L., Lane, C., Adak, G.K. and Threlfall, E.J. (2009) A Re-Evaluation of the Impact of Temperature and Climate Change on Foodborne Illness. Epidemiology \& Infection, 137, 1538-1547. https://doi.org/10.1017/S0950268809002477

[61] Kim, T.S., Kim, M.J., Kim, S.H., Seo, J.J., Kee, H.Y., Jung, J.K., Ha, D.R., Kim, E.S., Moon, Y.W., Lim, S.K., Kim, M.K. and Nam, H.M. (2012) Serotypes of Salmonella Isolated from Faeces of Patients with Acute Diarrhoea in Gwangju Area, Korea, during 2000-2009. Zoonoses and Public Health, 59, 482-489.

https://doi.org/10.1111/zph.12011

[62] HSU (2011) Health Statistics Unit: Health Statistics Report 2010. Ministry of Health and Quality of Life, Port Louis. http://health.govmu.org/English/Pages/default.aspx

[63] HSU (2012) Health Statistics Unit: Health Statistics Report 2011. Ministry of Health and Quality of Life, Port Louis. http://health.govmu.org/English/Pages/default.aspx

[64] HSU (2008) Health Statistics Unit: Health Statistics Report 2007. Ministry of Health and Quality of Life, Port Louis. http://health.govmu.org/English/Pages/default.aspx

[65] HSU (2009) Health Statistics Unit: Health Statistics Report 2008. Ministry of Health and Quality of Life, Port Louis. http://health.govmu.org/English/Pages/default.aspx

[66] HSU (2014) Health Statistics Unit: Health Statistics Report 2013. Ministry of Health and Quality of Life, Port Louis.

http://health.govmu.org/English/Pages/default.aspx 
[67] HSU (2015) Health Statistics Unit: Health Statistics Report 2014. Ministry of Health and Quality of Life, Port Louis. http://health.govmu.org/English/Pages/default.aspx

[68] Schielke, A., Rosner, B.M. and Stark, K. (2014) Epidemiology of campylobacteriosis in Germany-Insights from 10 Years of Surveillance. BMC Central Infectious Diseases, 14, 30-37. https://doi.org/10.1186/1471-2334-14-30

[69] Gaungoo, Y. and Jeewon, R. (2013) Effectiveness of Training among Food Handlers: A Review on the Mauritian Framework. Current Research in Nutrition and Food Science, 1, 1-9. https://doi.org/10.12944/CRNFSJ.1.1.01

[70] Issack, M.I., Hendriksen, R.S., Hyytiä-Trees, E., Svendsen, C.A. and Mikoleit, M. (2014) Emergence and Clonal Dissemination of Salmonella enterica Serovar Enteritidis Causing Salmonellosis in Mauritius. Journal of Infection in Developing Countries, 8, 454-460. https://doi.org/10.3855/jidc.3695

[71] WHO (2015) World Health Organisation: WHO Estimates of the Global Burden of Foodborne Diseases: Foodborne Disease Burden Epidemiology Reference Group 2007-2015. WHO, Geneva.

[72] Ministry of Health and Quality of Life (1998) Mauritian Food Act 1998. http://health.govmu.org/English/Legislations/Pages/Foodact1998.aspx

[73] Ministry of Health and Quality of Life (1999) Mauritian Food Act 1999. http://health.govmu.org/English/Documents/reg-food.pdf

[74] Olsen, S.J., MacKinnon, L.C., Goulding, J.S., Bean, N.H. and Slutsker, L. (2000) Surveillance for Foodborne Disease Outbreaks-United States, 1993-1997. Morbidity and Mortality Weekly Report, 49, 1-62.

[75] Green, R.M. and Kane, K. (2014) The Effective Enforcement of HACCP Based Food Safety Management Systems in the UK. Food Control, 37, 257-262.

https://doi.org/10.1016/j.foodcont.2013.09.016

[76] Business.mega.mu (2014) Dengue Fever: New Cases Detected. http://business.mega.mu/2014/03/28/dengue-fever-new-case-detected/

[77] L’Express.mu (2015) Fièvre dengue: deux nouveau cas détectés à Port-Louis (Dengue Fever: Two New Cases Detected at Port Louis).

http://www.lexpress.mu/article/260757/fievre-dengue-deux-nouveaux-cas-detectesport-louis

[78] Ramchurn, S.K., Goorah, S.S.D. and Makhan, M. (2010) An Analysis of the Excess Mortality Profile during the 2006 Chikungunya Fever Epidemic in Mauritius. Internet Journal of Medical Update, 5, 3-7.

[79] Pay Research Bureau: PRB Report 2013-Civil Service, PRB, Port Louis. http://prb.pmo.govmu.org/English/Pages/default.aspx

[80] Pillsbury, A., Chiew, M., Bates, J. and Sheppeard, V. (2013) An Outbreak of Staphylococcal Food Poisoning in a Commercially Catered Buffet. Communicable Diseases Intelligence Quarterly Report, 37, E144-E148.

[81] Australian New Zealand Food Standards Code (2003) http://www.foodstandards.gov.au/code/Pages/default.aspx

[82] Greig, J.D, Todd, E.C.D., Bartleson, C.A. and Michaels, B.S. (2007) Outbreaks Where Food Workers Have Been Implicated in the Spread of Foodborne Disease. Part 1. Description of the Problem, Methods, and Agents Involved. Journal of Food Protection, 70, 1752-1761. https://doi.org/10.4315/0362-028X-70.7.1752

[83] Emond, B. (2014) Food Safety First: Industry Training Needs. Food \& Drink Technology, 13, 12. 
[84] Shinbaum, S., Crandall, P.G. and O'Bryan, C.A. (2016) Evaluating Your Obligations for Employee Training According to the Food Safety Modernization Act. Food Control, 60, 12-17. https://doi.org/10.1016/j.foodcont.2015.07.014

[85] Park, S.-H., Kwak, T.-K. and Chang, H.-J. (2010) Evaluation of the Food Safety Training for Food Handlers in Restaurant Operations. Nutrition Research and Practice, 4, 58-68. https://doi.org/10.4162/nrp.2010.4.1.58

[86] Soares, L.S., Almeida, R.C.C., Cerqueira, E.S., Carvalho, J.S. and Nunes, I.L. (2012) Knowledge, Attitudes and Practices in Food Safety and the Presence of Coagulase-Positive Staphylococci on Hands of Food Handlers in the Schools of Camaçari, Brazil. Food Control, 27, 206-213. https://doi.org/10.1016/j.foodcont.2012.03.016

[87] Food Act in Victoria (1984) Authorised version No. 101. http://www.legislation.vic.gov.au/Domino/Web_Notes/LDMS/LTObject_Store/LT ObjSt7.nsf/DDE300B846EED9C7CA257616000A3571/DE3E7B8DD3E5864FCA257 B2E00047D70/\$FILE/84-10082aa101\%20authorised.pdf

[88] Liu, L.G., Zhou, X.Y., Lan, Z., Li, L., Li, Z., Chen, W., Wang, J.Y. and Zhang, L.J. (2016) Salmonella Typhimurium Outbreak Associated with a Contaminated Food Container in a School in Sichuan Province, China. Epidemiology and Infection, 144, 285-290. https://doi.org/10.1017/S0950268815001387

[89] Rajpura, A., Lamden, K., Forster, S., Clarke, S., Cheesbrough, J., Gornall, S. and Waterworth, S. (2003) Large Outbreak of Infection with Escherichia coli O157 PT21/28 in Eccleston, Lancashire, Due to Cross-Contamination at a Butcher's Counter. Communicable Disease and Public Health, 6, 279-284.

[90] Chiou, J., Leung, A.H.H., Lee, H.W. and Wong, W.-T. (2015) Review: Rapid Testing Methods for Food Contaminants and Toxicants. Journal of Integrative Agriculture, 14, 2243-2264. https://doi.org/10.1016/S2095-3119(15)61119-4 